\title{
Epitaxial Growth of MgxCa1-xO on GaN by Atomic Layer Deposition
}

\section{Citation}

Lou, Xiabing, Hong Zhou, Sang Bok Kim, Sami Alghamdi, Xian Gong, Jun Feng, Xinwei Wang, Peide D. Ye, and Roy G. Gordon. 2016. Epitaxial Growth of MgxCa1-xO on GaN by Atomic Layer Deposition. Nano Letters 16, no. 12: 7650-7654. doi:10.1021/acs.nanolett.6b03638.

\section{Published Version}

10.1021/acs.nanolett.6b03638

\section{Permanent link}

http://nrs.harvard.edu/urn-3:HUL.InstRepos:29995335

\section{Terms of Use}

This article was downloaded from Harvard University's DASH repository, and is made available under the terms and conditions applicable to Open Access Policy Articles, as set forth at http:// nrs.harvard.edu/urn-3:HUL.InstRepos:dash.current.terms-of-use\#OAP

\section{Share Your Story}

The Harvard community has made this article openly available.

Please share how this access benefits you. Submit a story.

Accessibility 


\section{Epitaxial Growth of $\mathrm{Mg}_{\mathrm{x}} \mathrm{Ca}_{1-\mathrm{x}} \mathrm{O}$ on $\mathrm{GaN}$ by Atomic Layer Deposition}

Xiabing Lou ${ }^{\dagger}$, Hong Zhou ${ }^{\ddagger}$, Sang Bok Kim ${ }^{\dagger}$, Sami Alghamdi ${ }^{\ddagger}$, Xian Gong ${ }^{\dagger}$, Jun Feng ${ }^{\dagger}$, Xinwei Wang ${ }^{\dagger \#}$, Peide D. Ye ${ }^{\ddagger}$, Roy G. Gordon ${ }^{\dagger}$

${ }^{\dagger}$ Department of Chemistry and Chemical Biology, Harvard University, Cambridge, Massachusetts

02138, United States

$¥$ School of Electrical and Computer Engineering and Birck Nanotechnology Center, Purdue

University, West Lafayette, Indiana 47906, United States

Corresponding Author: Roy G. Gordon, Email: gordon@chemistry.harvard.edu

Present Address:

\# School of Advanced Materials, Shenzhen Graduate School, Peking University, Shenzhen 518055,

China

Abstract: We demonstrate for the first time that a single-crystalline epitaxial $\mathrm{Mg}_{1-\mathrm{x}} \mathrm{Ca}_{\mathrm{x}} \mathrm{O}$ film can be deposited on gallium nitride $(\mathrm{GaN})$ by atomic layer deposition (ALD). By adjusting the ratio between the amounts of $\mathrm{Mg}$ and $\mathrm{Ca}$ in the film, a lattice matched $\mathrm{Mg}_{\mathrm{x}} \mathrm{Ca}_{1-\mathrm{x}} \mathrm{O} / \mathrm{GaN}(0001)$ interface can be achieved with low interfacial defect density. High resolution X-ray diffraction (XRD) shows that the lattice parameter of this ternary oxide nearly obeys Vegard's Law. An atomically sharp interface from cross-sectional transmission electron microscopy (TEM) confirmed the high quality of the epitaxy. High temperature capacitance-voltage characterization showed that the 
film with composition $\mathrm{Mg}_{0.25} \mathrm{Ca}_{0.75} \mathrm{O}$ has the lowest interfacial defect density. With this optimal oxide composition, a $\mathrm{Mg}_{0.25} \mathrm{Ca}_{0.75} \mathrm{O} / \mathrm{AlGaN} / \mathrm{GaN}$

metal-oxide-semiconductor high-electron-mobility (MOS-HEMT) device was fabricated. An ultra-high on/off ratio of $10^{12}$ and a near ideal SS of $62 \mathrm{mV} / \mathrm{dec}$ was achieved with this device.

KEYWORDS: Epitaxy, dielectric, GaN, MOS-HEMT, magnesium calcium oxide

The wide implementation of solar energy and fast development of electrical vehicles both require more efficient power electronic devices working under high voltage (>600V), high temperature $\left(>100{ }^{\circ} \mathrm{C}\right)$ and high frequency conditions. ${ }^{1}$ Currently, Si-based power devices could not meet these demands due to the small band gap (1.1 $\mathrm{eV}$ ) and low breakdown field of $\mathrm{Si}^{2} \mathrm{GaN}$ could replace Si for future power applications because of its higher band gap (3.4eV) and higher breakdown field. However, unlike $\mathrm{Si}$, the interface trap density between $\mathrm{GaN}$ and its native oxide $\left(\mathrm{Ga}_{2} \mathrm{O}_{3}\right)$ is huge, which prevents high efficiency modulation of GaN devices. Many alternative dielectrics, such as $\mathrm{HfO}_{2},{ }^{3} \mathrm{Al}_{2} \mathrm{O}_{3},{ }^{4} \mathrm{SiO}_{2},{ }^{5} \mathrm{Sc}_{2} \mathrm{O}_{3}$, etc, have been employed as dielectrics on $\mathrm{GaN}$ in various studies. However, GaN devices with a low defect interface and high quality dielectric have not been achieved with any material.

Recently, our group demonstrated that ALD can grow lanthanum oxide epitaxially on 
gallium arsenide (GaAs) (111)A surfaces, and that the density of interfacial defects is remarkably low. ${ }^{7}$ Although the (0001) surface of GaN wurtzite structure has an atomic structure similar to the (111)A surface of GaAs, it is more challenging to apply the same strategy to GaN due to the lack of any lattice matched oxide. We have also reported $\mathrm{ALD}-\mathrm{Sc}_{2} \mathrm{O}_{3}$ growth on $\mathrm{AlGaN} / \mathrm{GaN}$ based HEMT devices. ${ }^{6}$ Due to the large lattice mismatch between $\mathrm{Sc}_{2} \mathrm{O}_{3}$ and the substrate ( 9\%), epitaxial growth could not be achieved. $\mathrm{MgO}$ and $\mathrm{CaO}$, both have relatively high dielectric constants ( $\mathrm{MgO} 9.8$, $\mathrm{CaO}$ 11.8) and large band gaps (both $7 \sim 8 \mathrm{eV}$ ), and thus might be suitable gate oxides for $\mathrm{GaN}$. Moreover, the $\mathrm{GaN}$ lattice size lies between those of the $\mathrm{MgO}$ and $\mathrm{CaO}$ lattices (mismatch $-6.5 \%$ for $\mathrm{MgO}$ and $+6.5 \%$ for $\mathrm{CaO}$ ). Therefore, by tuning the composition of $\mathrm{Mg}_{\mathrm{x}} \mathrm{Ca}_{1-\mathrm{x}} \mathrm{O}$, a lattice match with $\mathrm{GaN}$ substrates can be achieved. Hellman et al. ${ }^{8}$ demonstrated that epitaxial $\mathrm{Mg}_{1-\mathrm{x}} \mathrm{Ca}_{\mathrm{x}} \mathrm{O}$ can be grown by molecular beam epitaxy (MBE) on $\mathrm{MgO}$ substrates. Later, Paisley et al. ${ }^{9}$ and Ren et al. ${ }^{10}$ reported that epitaxial $\mathrm{Mg}_{0.5} \mathrm{Ca}_{0.5} \mathrm{O}$ can be grown on $\mathrm{GaN}$ with the same method. Measurements on HEMTs with MBE-fabricated $\mathrm{MgCaO}$ insulators showed improved gate-lag. ${ }^{11}$ However, MBE is not applicable to large substrates needed for cost-effective industrial processing. Thus a more scalable and lower cost method to deposit epitaxial $\mathrm{Mg}_{\mathrm{x}} \mathrm{Ca}_{1-\mathrm{x}} \mathrm{O}$ is highly desirable.

In this work, we demonstrate that atomic layer deposition (ALD) can form $\mathrm{Mg}_{\mathrm{x}} \mathrm{Ca}_{1-\mathrm{x}} \mathrm{O}$ epitaxially on GaN(0001). Cross sectional transmission electron microscopy (TEM) 
determined the relationship of this heteroepitaxy to be $(111) \times[011] \mathrm{Mg}_{\mathrm{x}} \mathrm{Ca}_{1-\mathrm{x}} \mathrm{O} / / \mathrm{GaN}(0001) \times[11-20]$. High-resolution X-ray diffraction (HRXRD) and electron diffraction (ED) showed that the lattice constants of $\mathrm{Mg}_{\mathrm{x}} \mathrm{Ca}_{1-\mathrm{x}} \mathrm{O}$ with different compositions are close to the predictions of Vegard's Law. Capacitance-voltage $(\mathrm{C}-\mathrm{V})$ measurements were employed to study the interfacial defects and $\mathrm{Mg}_{0.25} \mathrm{Ca}_{0.75} \mathrm{O}$ showed the lowest density of defects. Additionally, an ultra-high on/off ratio of $10^{12}$ and a near-ideal subthreshold swing of $62 \mathrm{mV} / \mathrm{dec}$ were achieved with $\mathrm{Mg}_{0.25} \mathrm{Ca}_{0.75} \mathrm{O}$ as a gate oxide of $\mathrm{GaN}$ MOS-HEMT. This is the first demonstration of epitaxial $\mathrm{Mg}_{\mathrm{x}} \mathrm{Ca}_{1-\mathrm{x}} \mathrm{O}$ in a GaN/AlGaN/GaN MOS-HEMT device. The results show that the $\mathrm{Mg}_{\mathrm{x}} \mathrm{Ca}_{1-\mathrm{x}} \mathrm{O}$ dielectric is promising for applications in high-frequency and power electronics.

ALD of $\mathrm{Mg}_{\mathrm{x}} \mathrm{Ca}_{1-\mathrm{x}} \mathrm{O}$ was carried out in a home-built tubular reactor ${ }^{12}$. $\operatorname{Bis}(N, N$ '-diisopropylacetamidinato $)$ calcium(II) dimer ${ }^{13}$, $\operatorname{bis}\left(N, N^{\prime}\right.$-di-sec-butylacetamidinato)magnesium ${ }^{14}$ and $\mathrm{H}_{2} \mathrm{O}$ were used as calcium, magnesium and oxygen sources, respectively. Structural formulas for the $\mathrm{Mg}$ and $\mathrm{Ca}$ precursors are shown in Fig. 1. Three different precursor dosing ratios, namely $\mathrm{Mg}: \mathrm{Ca}=1: 1, \mathrm{Mg}: \mathrm{Ca}=1: 2$ and $\mathrm{Mg}: \mathrm{Ca}=1: 3$, were employed. The compositions of the resulting films were determined by Rutherford Backscattering Spectroscopy (RBS) to be $\mathrm{Mg}_{0.72} \mathrm{Ca}_{0.28} \mathrm{O}, \mathrm{Mg}_{0.51} \mathrm{Ca}_{0.49} \mathrm{O}$ and $\mathrm{Mg}_{0.25} \mathrm{Ca}_{0.75} \mathrm{O}$, respectively. The detailed growth conditions are summarized in supporting information. The depositions below a 
substrate temperature of $290{ }^{\circ} \mathrm{C}$ were not well crystalized while carbon impurity can be detected at above $330{ }^{\circ} \mathrm{C}$. Therefore, an optimal growth temperature is determined to be $310{ }^{\circ} \mathrm{C}$. The film growth rates with different dosing ratios and the corresponding compositions are summarized in Table 1. For all three compositions, the growth rates are slightly smaller than a linear combination of the $\mathrm{MgO}$ and $\mathrm{CaO}$ growth rates, and the $\mathrm{Mg}$ contents are higher than their corresponding dosing ratio in the 1:1 and 1:2 cases. This indicates that the $\mathrm{MgO}$ cycle might have a hindering effect on the reaction of the $\mathrm{CaO}$ deposition cycle. Although $\mathrm{MgO}$ and $\mathrm{CaO}$ are nearly immiscible at equilibrium below $2000{ }^{\circ} \mathrm{C},{ }^{15}$ this solid mixture is kinetically stable up to about 600 ${ }^{\circ} \mathrm{C} .{ }^{16}$

One powerful method to examine the epitaxial film quality is cross-sectional TEM imaging. Figure 2 summarizes the cross-section TEM images of three different $\mathrm{Mg}_{\mathrm{x}} \mathrm{Ca}_{1-\mathrm{x}} \mathrm{O} / \mathrm{GaN}$ samples. Since $\mathrm{GaN}$ and $\mathrm{Mg}_{\mathrm{x}} \mathrm{Ca}_{1-\mathrm{x}} \mathrm{O}$ have different crystal structures, their lattice patterns in TEM are different. The GaN region shows a distinctive three atomic line periodicity pattern in the vertical direction while $\mathrm{Mg}_{\mathrm{x}} \mathrm{Ca}_{1-\mathrm{x}} \mathrm{O}$ does not have this feature. All three samples show sharp interfaces without any interfacial layer. The nearly perfect single crystal lattices in Fig. $\mathbf{2}$ a and $\mathbf{b}$ confirmed the high quality of epitaxy of $\mathrm{Mg}_{0.25} \mathrm{Ca}_{0.75} \mathrm{O}$ and $\mathrm{Mg}_{0.51} \mathrm{Ca}_{0.49} \mathrm{O}$ on $\mathrm{GaN}$. On the other hand, the grain boundaries in Fig. 2 c indicate that a highly textured $\mathrm{Mg}_{0.72} \mathrm{Ca}_{0.28} \mathrm{O}$ film is formed on GaN. The well-defined film spots in the diffraction pattern (Fig. S2) also confirmed 
the high quality of epitaxial $\mathrm{Mg}_{0.25} \mathrm{Ca}_{0.75} \mathrm{O}$ and $\mathrm{Mg}_{0.51} \mathrm{Ca}_{0.49} \mathrm{O}$ films while the $\mathrm{Mg}_{0.72} \mathrm{Ca}_{0.28} \mathrm{O}$ film has some textured features. Moreover, from the diffraction pattern, the zone axis of the GaN substrate in these TEM images is [11-20], while the film zone axis can be determined as [011]. Therefore, the epitaxial relation between the film and substrate is $(111) \times[0-11] \mathrm{Mg}_{\mathrm{x}} \mathrm{Ca}_{1-\mathrm{x}} \mathrm{O} / / \mathrm{GaN}(0001) \times[11-20]$.

In order to study the lattice mismatch between $\mathrm{Mg}_{\mathrm{x}} \mathrm{Ca}_{1-\mathrm{x}} \mathrm{O}$ film and $\mathrm{GaN}$ substrate, coupled $2 \theta-\omega$ HRXRD scans were employed. Both $\mathrm{GaN}(0004)$ and $\mathrm{Mg}_{\mathrm{x}} \mathrm{Ca}_{1-\mathrm{x}} \mathrm{O}(222)$ peaks are seen in all three samples (Fig. 3 a). The absence of $\mathrm{MgO}$ and $\mathrm{CaO}$ peaks indicates that phase separation into the two binaries has not occurred. The $\mathrm{Mg}_{\mathrm{x}} \mathrm{Ca}_{1-\mathrm{x}} \mathrm{O}(222)$ peak shifts to lower $2 \theta$ position as the Ca content increases. Both measured lattice constants and the calculated lattice constants based on Vegard's Law are plotted in Fig. 3 b. Assuming a fully relaxed hetero-epitaxial relation at the interface and considering the epitaxial relationship between the film and the substrate, the out-of-plane lattice mismatch can be defined as: $\left(\mathrm{a}_{\mathrm{MgCaO}(222)}-\mathrm{a}_{\mathrm{GaN}(0004)}\right) / \mathrm{a}_{\mathrm{GaN}(0004) .}{ }^{7}$ The mismatch is $-1.2 \%$ for $\mathrm{Mg}_{0.72} \mathrm{Ca}_{0.28} \mathrm{O},+2.4 \% \mathrm{Mg}_{0.51} \mathrm{Ca}_{0.49} \mathrm{O}$ and $+3.1 \%$ for $\mathrm{Mg}_{0.25} \mathrm{Ca}_{0.75} \mathrm{O}$. Similar lattice mismatch values obtained from in-plane FFT analysis of TEM cross-sectional images also confirmed the relaxed interface. (Fig. S8) Despite the larger lattice mismatch, $\mathrm{Mg}_{0.51} \mathrm{Ca}_{0.49} \mathrm{O}$ and $\mathrm{Mg}_{0.25} \mathrm{Ca}_{0.75} \mathrm{O}$ show nearly perfect epitaxy while $\mathrm{Mg}_{0.72} \mathrm{Ca}_{0.28} \mathrm{O}$, with a smaller mismatch, exhibits a textured structure. Such results indicate that there might be factors other than mismatch affecting the 
epitaxial quality.

Although $\mathrm{MgO}$ and $\mathrm{CaO}$ are immiscible with each other below $2000{ }^{\circ} \mathrm{C}^{15}$, previous reports ${ }^{9,17}$ have shown that $\mathrm{Mg}_{\mathrm{x}} \mathrm{Ca}_{1-\mathrm{x}} \mathrm{O}$ can be grown by $\mathrm{MBE}$ at lower temperature without phase separation. In order to examine the microscopic crystallinity and phase composition of the $\mathrm{Mg}_{\mathrm{x}} \mathrm{Ca}_{1-\mathrm{x}} \mathrm{O}$ films deposited by this ALD method, transmission electron microscopy (TEM) was employed. As shown in supporting information, the ring diffraction pattern in Fig. S1 (b) clearly indicates that film is polycrystalline on $\mathrm{SiN}_{\mathrm{x}}$. The relative positions between different diffraction rings in the electron diffraction pattern are in accord with the FCC standard pattern. This indicates that the $\mathrm{Mg}_{\mathrm{x}} \mathrm{Ca}_{1-\mathrm{x}} \mathrm{O}$ shares the same rock salt structure with $\mathrm{MgO}$ and $\mathrm{CaO}$. Additionally, the values of the lattice spacings lie in between the corresponding spacings in $\mathrm{MgO}$ and $\mathrm{CaO}$, showing that the $\mathrm{Mg}_{\mathrm{x}} \mathrm{Ca}_{1-\mathrm{x}} \mathrm{O}$ film is a uniform alloy of the two components without phase separation.

In summary of the above structural characterizations, $\mathrm{Mg}_{\mathrm{x}} \mathrm{Ca}_{1-\mathrm{x}} \mathrm{O}$ films deposited by ALD were proved to be epitaxial on GaN by both TEM and XRD. Cross sectional TEM revealed near perfect epitaxy of $\mathrm{Mg}_{0.51} \mathrm{Ca}_{0.49} \mathrm{O}$ and $\mathrm{Mg}_{0.25} \mathrm{Ca}_{0.75} \mathrm{O}$ on $\mathrm{GaN}$. However, although a smaller lattice mismatch was found in $\mathrm{Mg}_{0.72} \mathrm{Ca}_{0.28} \mathrm{O} / \mathrm{GaN}$, the epitaxy was not as perfect as for the other two compositions. Therefore lattice mismatch might not be the only parameter affecting the quality of epitaxy. 
$\mathrm{Mg}_{\mathrm{x}} \mathrm{Ca}_{1-\mathrm{x}} \mathrm{O} / \mathrm{GaN}$ MOS-capacitor devices were fabricated to examine the electrical performance by capacitance-voltage and conductance-voltage measurements. Since $\mathrm{GaN}$ has a wide band gap of $3.4 \mathrm{eV}$, a room temperature $\mathrm{CV}$ does not effectively probe defects near the middle of the bandgap. Therefore, the MOS-capacitors were measured at $150{ }^{\circ} \mathrm{C}$ as well as at room temperature. Due to the hydroscopic nature of $\mathrm{Mg}_{\mathrm{x}} \mathrm{Ca}_{1-\mathrm{x}} \mathrm{O}, 5 \mathrm{~nm}$ of $\mathrm{Al}_{2} \mathrm{O}_{3}$ were deposited as a capping layer to keep moisture away from the $\mathrm{Mg}_{\mathrm{x}} \mathrm{Ca}_{1-\mathrm{x}} \mathrm{O}$ layer. An amorphous $\mathrm{Al}_{2} \mathrm{O}_{3} / \mathrm{GaN}$ MOS was also prepared for comparison. A "top-to-top" capacitor structure was used to measure the capacitance due to the insulating sapphire substrate under the GaN (Fig. S3). In this measurement, the positive probe is placed in contact with the gate electrode while the negative probe is in contact with the large area of GaN covered by aluminum metal. Since the gate has a serial connection with the large area, the measured capacitance is given by $1 / C_{m}=1 / C_{g}+1 / C_{l}$, where $C_{m}$ is the capacitance measured by the LCR meter, $C_{g}$ is the capacitance of the gate and $C_{l}$ is the capacitance of the larger area. Since $\mathrm{C}_{\ell} \gg \mathrm{C}_{\mathrm{g}}$, the measured capacitance is dominated by the gate: $C_{m} \approx C_{g}$.

The measured room temperature and high temperature CV curves from three $\mathrm{Mg}_{\mathrm{x}} \mathrm{Ca}_{1-\mathrm{x}} \mathrm{O} / \mathrm{GaN}$ samples as well as an $\mathrm{Al}_{2} \mathrm{O}_{3} / \mathrm{GaN}$ sample are summarized in Fig. 4. In room temperature studies (Fig. 4 a, b and c), very small $(<6 \%)$ frequency dispersion can be seen in the depletion region for all three $\mathrm{Mg}_{\mathrm{x}} \mathrm{Ca}_{1-\mathrm{x}} \mathrm{O}$ samples, while 
there is a $20 \%$ dispersion in the same region in the $\mathrm{Al}_{2} \mathrm{O}_{3} / \mathrm{GaN}$ sample (Fig. 4 d). In the absence of interface traps, dispersion should not occur. Therefore the reduced dispersion in the three $\mathrm{Mg}_{\mathrm{x}} \mathrm{Ca}_{1-\mathrm{x}} \mathrm{O}$ samples compared to the $\mathrm{Al}_{2} \mathrm{O}_{3}$ sample qualitatively indicates that the epitaxial film did reduce the number of interfacial traps. Due to the low interfacial trap density, a numerical value for $\mathrm{D}_{\mathrm{it}}$ could not be extracted from the room temperature $\mathrm{CV}$ measurements. During the $\mathrm{CV}$ measurement, the Fermi level is moved deeper in the band gap at a higher temperature; thus defect information can be obtained over a wider range of energies within the band gap. ${ }^{18}$ In the CV data taken at $150{ }^{\circ} \mathrm{C}(\mathbf{F i g} . \mathbf{4} \mathbf{e , f}, \mathbf{g}$ and $\mathbf{h})$, the frequency dispersion remained relatively small $(<6 \%)$ for all three $\mathrm{Mg}_{\mathrm{x}} \mathrm{Ca}_{1-\mathrm{x}} \mathrm{O}$ samples while the dispersion in $\mathrm{Al}_{2} \mathrm{O}_{3} / \mathrm{GaN}$ is as large as $100 \%$. The smaller frequency dispersion at high temperature indicates that the $\mathrm{Mg}_{\mathrm{x}} \mathrm{Ca}_{1-\mathrm{x}} \mathrm{O}$ film effectively reduced the interfacial trap density near the midgap region compared to $\mathrm{Al}_{2} \mathrm{O}_{3}$. In order to measure the $\mathrm{D}_{\text {it }}$ values quantitatively, the conductance method was employed since the Terman method is considered less sensitive ${ }^{19}$ and the Gray-Brown method is not applicable to III-V semiconductors. ${ }^{20}$ The detailed measurement procedure and conductance data are summarized in the supporting information(Fig. S5). ${ }^{18}$ The measured values of $\mathrm{D}_{\mathrm{it}}$ are summarized in Fig. 4 i. Two of the samples with epitaxial films show the lowest $D_{i t}$ values, while the textured sample has about one order of magnitude higher interfacial trap density. Although the lattice mismatch of the $\mathrm{Mg}_{0.25} \mathrm{Ca}_{0.75} \mathrm{O}$ sample is slightly larger than that of the other two $\mathrm{Mg}_{\mathrm{x}} \mathrm{Ca}_{1-\mathrm{x}} \mathrm{O}$ samples, the measured $\mathrm{D}_{\mathrm{it}}$ level is the lowest $\left(\sim 5 \times 10^{12} \mathrm{eV}^{-1} \mathrm{~cm}^{-2}\right)$. One possible explanation is that during the early ALD 
cycles, the Ca growth rate is smaller than that of the $\mathrm{Mg}$. Thus the Ca content near the interface is lower than in the bulk $\mathrm{Mg}_{\mathrm{x}} \mathrm{Ca}_{1-\mathrm{x}} \mathrm{O}$ film. Another possible explanation is that a trace amount of $\mathrm{Mg}(\mathrm{OH})_{2}$ may also cause interfacial traps, while adding more Ca content may help reduce the number of hydroxyl groups and therefore reduce the $\mathrm{D}_{\text {it }}$ level. The dielectric constant of the $\mathrm{Mg}_{0.25} \mathrm{Ca}_{0.75} \mathrm{O}$ film derived from the $\mathrm{CV}$ measurement is 10 , which is close to the permittivities of $\mathrm{MgO}$ and $\mathrm{CaO}$.

The ultimate goal of developing this material is implementing $\mathrm{Mg}_{\mathrm{x}} \mathrm{Ca}_{1-\mathrm{x}} \mathrm{O}$ into $\mathrm{GaN}$ MOS-HEMT devices with unprecedented oxide/semiconductor interface quality. A schematic cross section of such a device is shown in Fig. 5 a. The fabrication process is summarized in supporting information. The $\mathrm{Mg}_{0.25} \mathrm{Ca}_{0.75} \mathrm{O}$ film was used as the gate dielectric in this study due to its lower $\mathrm{D}_{\text {it }}$. The gate oxide stack is $\mathrm{Al}_{2} \mathrm{O}_{3}(5 \mathrm{~nm}) / \mathrm{Mg}_{0.25} \mathrm{Ca}_{0.75} \mathrm{O}(10 \mathrm{~nm}) / \mathrm{GaN}$. Well-behaved $\mathrm{I}_{\mathrm{d}}-\mathrm{V}_{\mathrm{ds}}$ and linear-scale $\mathrm{I}_{\mathrm{d}}-\mathrm{V}_{\mathrm{gs}}$ curves (Fig. $\mathbf{5} \mathbf{b}$ and $\mathbf{d}$ ) show the good control capability of the GaN MOS-HEMT. Fig. $5 \mathrm{c}$ shows the transfer characteristics in a $\log$-scale plot at $\mathrm{V}_{\mathrm{ds}}=1 \mathrm{~V}$ and $5 \mathrm{~V}$, respectively. This device possesses an ultra-high on/off ratio $10^{12}$ due to the high quality interface. Thus the channel can be shut off completely. This value is two orders of magnitude higher than those HEMT devices with $\mathrm{Al}_{2} \mathrm{O}_{3}$ passivation. ${ }^{21}$ In addition to the ultra-high on/off ratio, the GaN MOS-HEMT also possesses a near ideal subthreshold swing (SS) of $62 \mathrm{mV} / \mathrm{dec}$, further confirming the high quality interface between $\mathrm{GaN}$ and the $\mathrm{Mg}_{0.25} \mathrm{Ca}_{0.75} \mathrm{O}$ layer. ${ }^{22}$ The successful implementation 
of the $\mathrm{Mg}_{0.25} \mathrm{Ca}_{0.75} \mathrm{O}$ into a GaN MOS-HEMT shows that it's promising for use in GaN MOS technology.

Epitaxial $\mathrm{Mg}_{\mathrm{x}} \mathrm{Ca}_{1-\mathrm{x}} \mathrm{O}$ films have been successfully grown on $\mathrm{GaN}$ [0001] surfaces using ALD for the first time. The crystallographic relationship of this hetero-epitaxy has been studied in detail. Moreover, the potential of applying this unprecedentedly high-quality dielectric film has been evaluated with $\mathrm{C}-\mathrm{V}$ characterization, revealing that the density of defects is affected by not only the lattice mismatch but also by the composition of the film. $\mathrm{Mg}_{0.25} \mathrm{Ca}_{0.75} \mathrm{O}$ is found to provide the interface with the fewest traps and the MOS-HEMT made from it exhibits an ultra-high on/off ratio of $10^{12}$ and a near ideal SS of $62 \mathrm{mV} / \mathrm{dec}$. Thus we believe this epitaxial $\mathrm{Mg}_{\mathrm{x}} \mathrm{Ca}_{1-\mathrm{x}} \mathrm{O}$ film can provide improved high-frequency and high-power electronics in the future. 


\begin{tabular}{|l|l|l|l|l|}
\hline $\begin{array}{l}\text { Dosing ratio } \\
\mathrm{Mg}: \mathrm{Ca}\end{array}$ & $\begin{array}{l}\text { Average growth } \\
\text { rate }(\mathrm{nm} / \text { cycle })\end{array}$ & Composition & $\begin{array}{l}\text { Lattice constant } \\
(\mathrm{nm})\end{array}$ & $\begin{array}{l}\text { Vagard's Law } \\
\text { prediction }(\mathrm{nm})\end{array}$ \\
\hline $\mathrm{CaO}$ & 0.075 & $\mathrm{CaO}$ & 0.1389 & 0.1389 \\
\hline $1: 3$ & 0.05 & $\mathrm{Mg}_{0.25} \mathrm{Ca}_{0.75} \mathrm{O}$ & 0.134 & 0.1345 \\
\hline $1: 2$ & 0.05 & $\mathrm{Mg}_{0.51} \mathrm{Ca}_{0.49} \mathrm{O}$ & 0.133 & 0.1299 \\
\hline $1: 1$ & 0.06 & $\mathrm{Mg}_{0.72} \mathrm{Ca}_{0.28} \mathrm{O}$ & 0.128 & 0.1262 \\
\hline $\mathrm{MgO}$ & 0.05 & $\mathrm{MgO}$ & 0.1213 & 0.1213 \\
\hline
\end{tabular}

Table 1.Summary of ALD growth rates, compositions and lattice constants of different $\mathrm{Mg}_{\mathrm{x}} \mathrm{Ca}_{1-\mathrm{x}} \mathrm{O}$ films. The composition was measured by Rutherford back scattering (RBS). Lattice constants of $\mathrm{Mg}_{\mathrm{x}} \mathrm{Ca}_{1-\mathrm{x}} \mathrm{O}$ (222) were measured by HRXRD. $\mathrm{MgO}$ and $\mathrm{CaO}$ (222) lattice constants were from Crystallography Open Database.

(a)

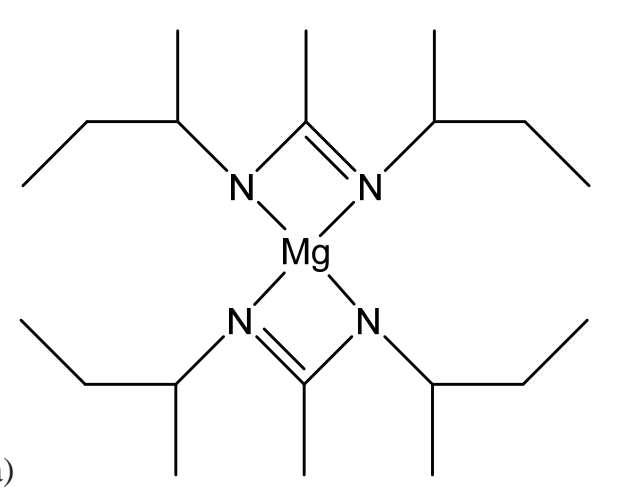

(b)

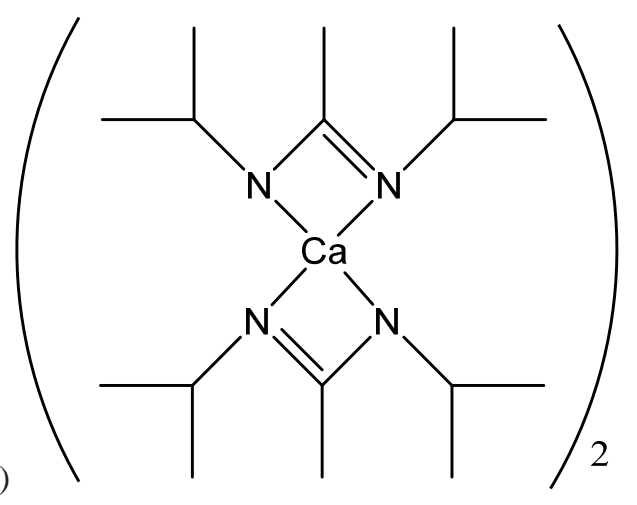

Figure 1. Structures of the metal precursors. (a)

$\operatorname{bis}\left(N, N^{\prime}\right.$-di-sec-butylacetamidinato)magnesium; (b)

$\operatorname{bis}(N, N$ '-diisopropylacetamidinato)calcium(II) dimer. 

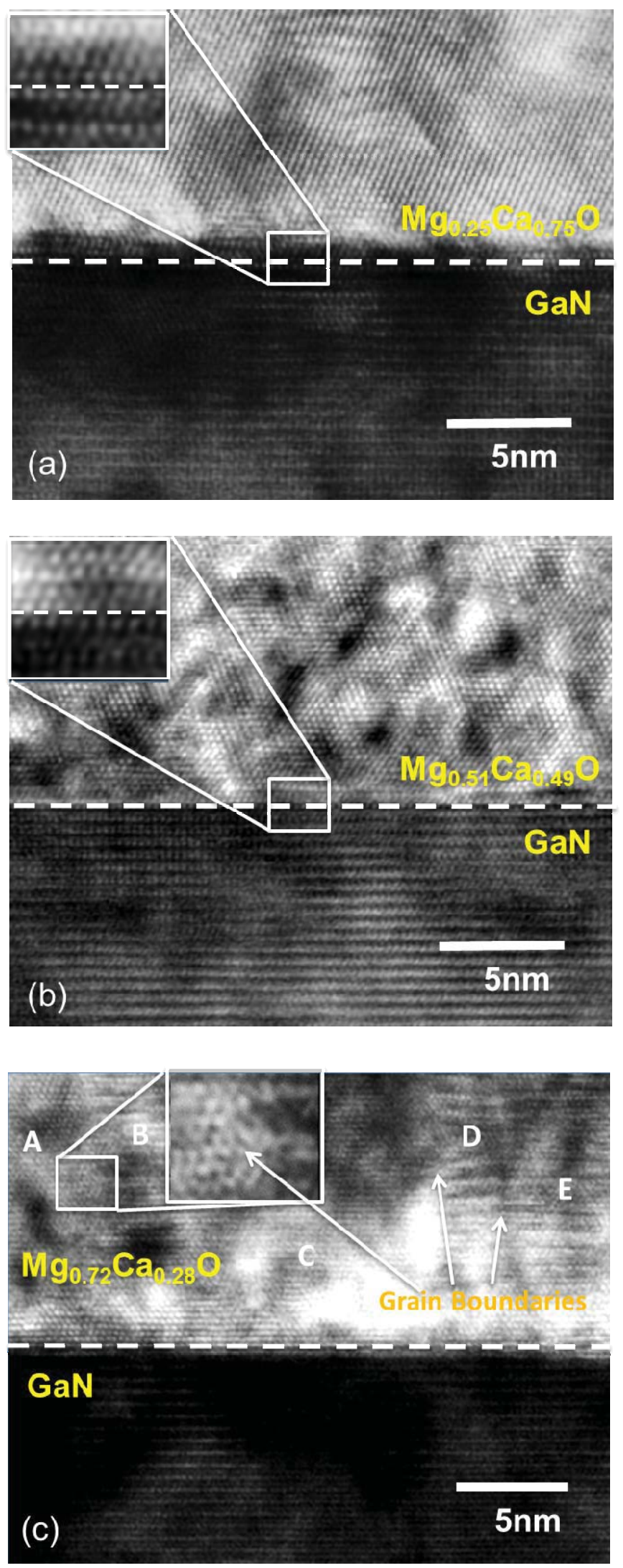
Figure 2. Cross-sectional TEM of $\mathrm{Mg}_{\mathrm{x}} \mathrm{Ca}_{1-\mathrm{x}} \mathrm{O}$ films grown on $\mathrm{GaN}(0001)$ surface. (a) $\mathrm{Mg}_{0.25} \mathrm{Ca}_{0.75} \mathrm{O} / \mathrm{GaN}$; (b) $\mathrm{Mg}_{0.51} \mathrm{Ca}_{0.49} \mathrm{O} / \mathrm{GaN}$; (c) $\mathrm{Mg}_{0.72} \mathrm{Ca}_{0.28} \mathrm{O} / \mathrm{GaN}$, grain boundaries can be found between each region labeled with letters. The enlarged grain boundary between region A and B shows both darkness contrast as well as pattern difference. Region B is showing a three line repeating pattern, which indicates two different orientation grains are overlapping together. Similar pattern can also be found in regions D and E.
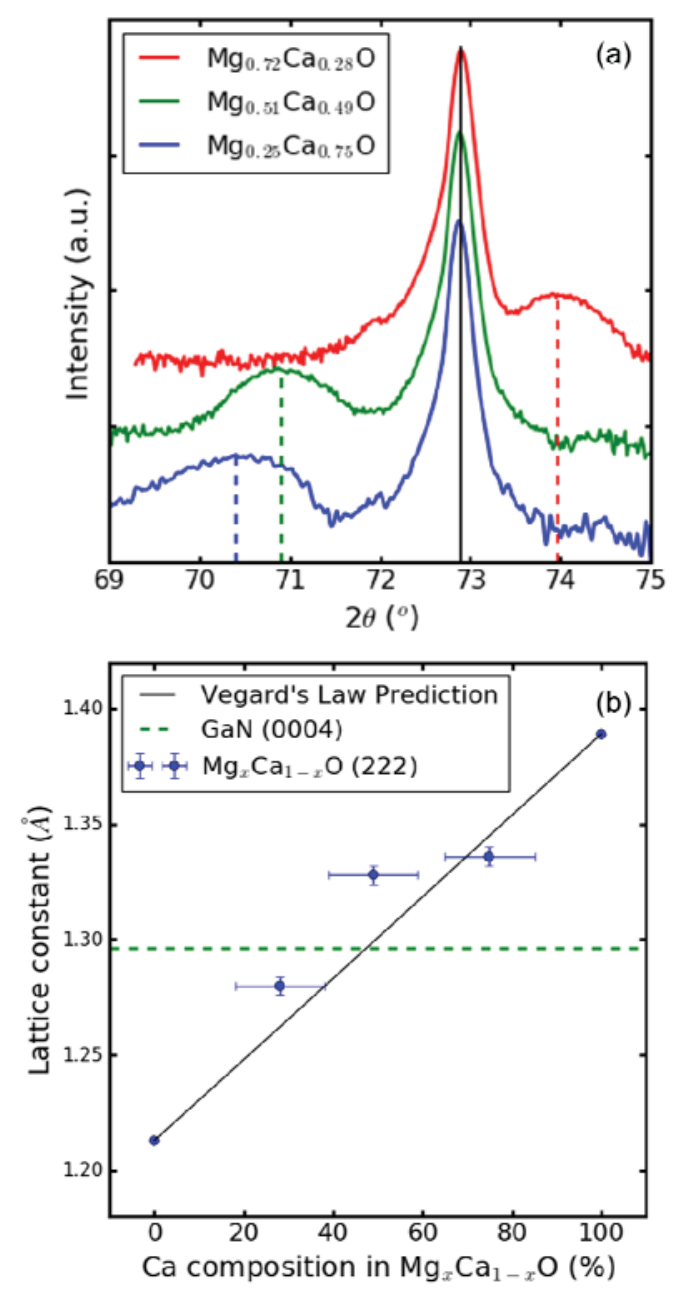

Figure 3. Lattice constant study by HRXRD. (a) HRXRD study of $\mathrm{Mg}_{\mathrm{x}} \mathrm{Ca}_{1-\mathrm{x}} \mathrm{O} / \mathrm{GaN}$ film. The black vertical line is the peak position of $\mathrm{GaN}(0004)$ diffraction. The dashed lines represent the peak positions of the $\mathrm{Mg}_{\mathrm{x}} \mathrm{Ca}_{1-\mathrm{x}} \mathrm{O}$ (222) diffractions; (b) Vegard's Law predicted lattice | constant vs XRD measured poly-crystalline $\mathrm{Mg}_{\mathrm{x}} \mathrm{Ca}_{1-\mathrm{x}} \mathrm{O}$ (222) lattice constants. The green dashed line is the lattice constant that matches the $\mathrm{GaN}(0004)$ lattice. 

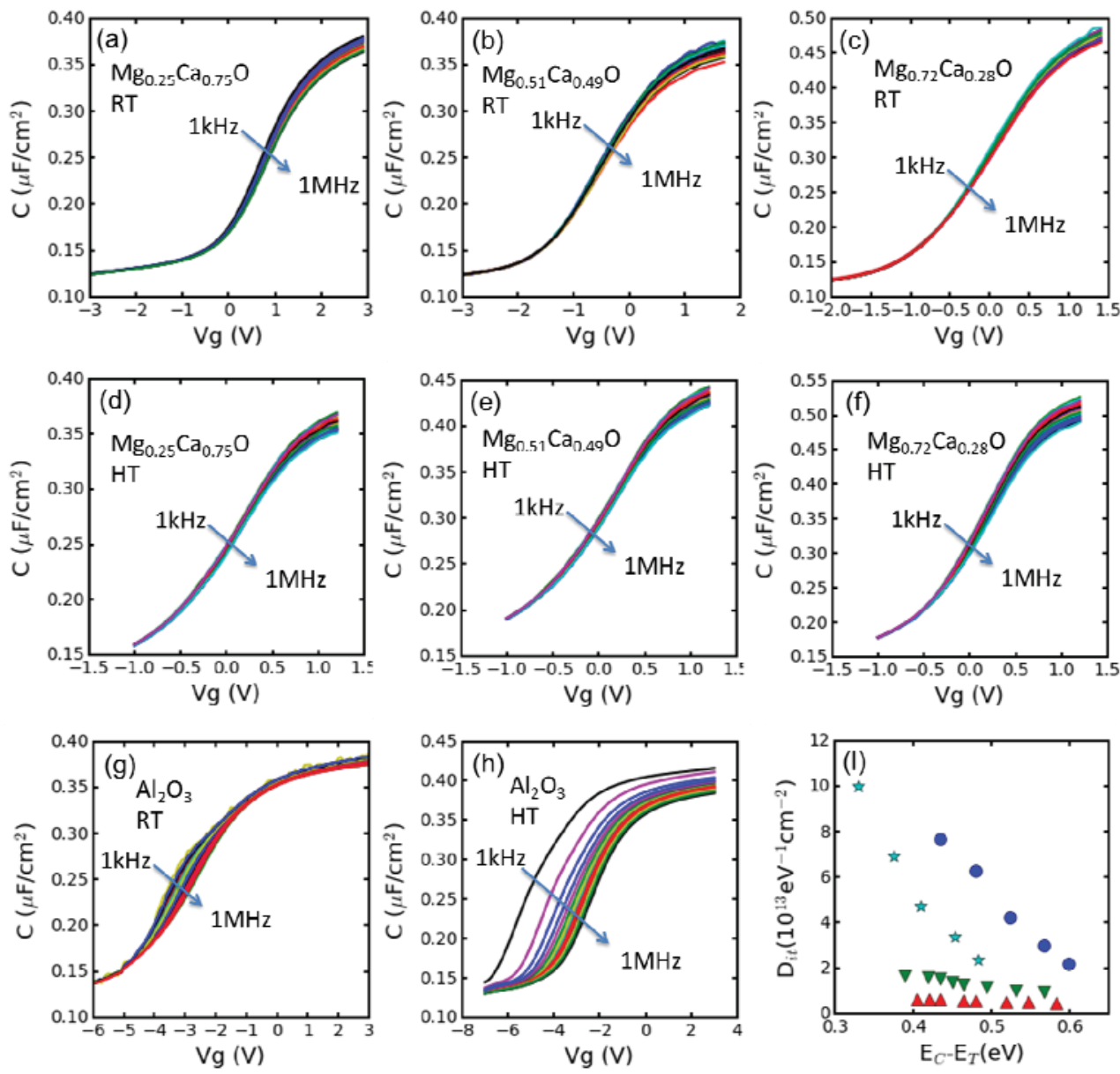

Figure 4. $\mathrm{C}-\mathrm{V}$ measurements for $\mathrm{Mg}_{\mathrm{x}} \mathrm{Ca}_{1-\mathrm{x}} \mathrm{O} / \mathrm{GaN}$ and $\mathrm{Al}_{2} \mathrm{O}_{3} / \mathrm{GaN}$ samples. The frequency ranges of all samples are from $1 \mathrm{kHz}$ to $1 \mathrm{MHz}$. (a) $20^{\circ} \mathrm{C} \mathrm{Al}_{2} \mathrm{O}_{3}(5 \mathrm{~nm}) / \mathrm{Mg}_{0.25} \mathrm{Ca}_{0.75} \mathrm{O}(15 \mathrm{~nm}) / \mathrm{GaN}$; (b) $20^{\circ} \mathrm{C}$ $\mathrm{Al}_{2} \mathrm{O}_{3}(5 \mathrm{~nm}) / \mathrm{Mg}_{0.51} \mathrm{Ca}_{0.49} \mathrm{O}(15 \mathrm{~nm}) / \mathrm{GaN}$; (c) $20^{\circ} \mathrm{C} \mathrm{Al}_{2} \mathrm{O}_{3}(5 \mathrm{~nm}) / \mathrm{Mg}_{0.72} \mathrm{Ca}_{0.28} \mathrm{O}(15 \mathrm{~nm}) / \mathrm{GaN}$; (d) $150^{\circ} \mathrm{C} \mathrm{Al}_{2} \mathrm{O}_{3}(5 \mathrm{~nm}) / \mathrm{Mg}_{0.25} \mathrm{Ca}_{0.75} \mathrm{O}(15 \mathrm{~nm}) / \mathrm{GaN}$. (e) $150^{\circ} \mathrm{C} \mathrm{Al}_{2} \mathrm{O}_{3}(5 \mathrm{~nm}) / \mathrm{Mg}_{0.51} \mathrm{Ca}_{0.49} \mathrm{O}(15 \mathrm{~nm}) / \mathrm{GaN}$; (f) $150^{\circ} \mathrm{C} \mathrm{Al}_{2} \mathrm{O}_{3}(5 \mathrm{~nm}) / \mathrm{Mg}_{0.72} \mathrm{Ca}_{0.28} \mathrm{O}(15 \mathrm{~nm}) / \mathrm{GaN}$; (g) $20^{\circ} \mathrm{C} \mathrm{Al}_{2} \mathrm{O}_{3}(20 \mathrm{~nm}) / \mathrm{GaN}$ for comparison; (h) $\mathrm{Al}_{2} \mathrm{O}_{3}(20 \mathrm{~nm}) / \mathrm{GaN}$; (i) $\mathrm{D}_{\text {it }}$ summary of four samples determined by the conductance method: $\mathrm{Al}_{2} \mathrm{O}_{3}(20 \mathrm{~nm}) / \mathrm{GaN}$ (light blue star * ), $\mathrm{Al}_{2} \mathrm{O}_{3}(5 \mathrm{~nm}) / \mathrm{Mg}_{0.72} \mathrm{Ca}_{0.28} \mathrm{O}(15 \mathrm{~nm}) / \mathrm{GaN}$ (blue circles $\bullet$ ), $\mathrm{Al}_{2} \mathrm{O}_{3}(5 \mathrm{~nm}) / \mathrm{Mg}_{0.51} \mathrm{Ca}_{0.49} \mathrm{O}(15 \mathrm{~nm}) / \mathrm{GaN}$ (green down triangle $\mathbf{\nabla}$ ) and $\mathrm{Al}_{2} \mathrm{O}_{3}(5 \mathrm{~nm}) / \mathrm{Mg}_{0.25} \mathrm{Ca}_{0.75} \mathrm{O}(15 \mathrm{~nm}) / \mathrm{GaN}($ red up triangles $\boldsymbol{\Delta})$ 


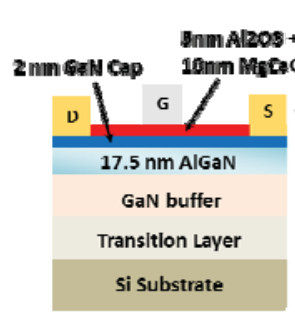

(a)

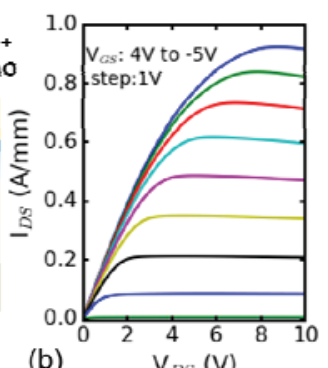

(b)
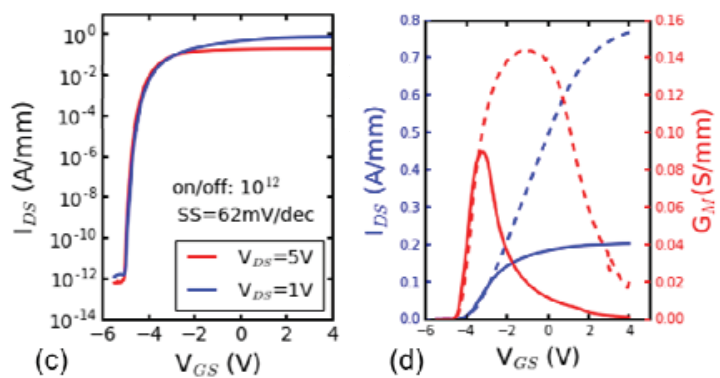

Figure 5. MOS-HEMT device performance characterization. a) Schematic of the $\mathrm{Mg}_{\mathrm{x}} \mathrm{Ca}_{1-\mathrm{x}} \mathrm{O}$ MOS-HEMT device; b) Transfer characteristics of the $\mathrm{Mg}_{0.25} \mathrm{Ca}_{0.75} \mathrm{O} / \mathrm{GaN} / \mathrm{AlGaN} / \mathrm{GaN}$ MOS-HEMT device; c) I-V characteristics comparison between two different source drain voltage; d) Conductivity and current vs gate voltage study. Solid lines represent $V_{D S}=5 \mathrm{~V}$, dashed lines represent $\mathrm{V}_{\mathrm{DS}}=1 \mathrm{~V}$. 
Supporting Information

Methods, TEM diffraction patterns of $\mathrm{Mg}_{\mathrm{x}} \mathrm{Ca}_{1-\mathrm{x}} \mathrm{O} / \mathrm{GaN}$, MOS-HEMT and MOS-capacitor

fabrication, $\mathrm{AC}$ conductance method to extract $\mathrm{D}_{\mathrm{it}}$.

Acknowledgements

The work at Harvard University is supported by the Center for the Next Generation of Materials by

Design, an Energy Frontier Research Center funded by the U.S. DOE, Office of Science. The work at Purdue University is supported in part by AFOSR (FA9550-12-1-0180) and in part by Award N000141512833 from ONR. Some of the work was performed at Harvard University's Center for Nanoscale Systems (CNS), a member of the National Nanotechnology Infra-Structure Network (NNIN) and at Harvard's X-ray laboratory. We would like to thank Kelson Chabak from AFRL for providing the high-quality $\mathrm{AlGaN} / \mathrm{GaN}$ on $\mathrm{Si}$ wafers for this research.

References

(1) Hensel, A.; Wilhelm, C.; Kranzer, D. IEEE Int. Power Electron. Motion Control Conf. 2012, DS3d.4-1-DS3d.4-5.

(2) Ikeda, N.; Li, J.; Kato, S.; Masuda, M.; Yoshida, S. Furukawa Rev. 2006, No. 29, 1-6.

(3) Tang, Z. J.; Li, R.; Yin, J. J. Mater. Sci. Mater. Electron. 2014, 25 (1), 152-156.

(4) Kang, H.-S.; Reddy, M. S. P.; Kim, D.-S.; Kim, K.-W.; Ha, J.-B.; Lee, Y. S.; Choi, H.-C.; Lee, J.-H. J. Phys. D. Appl. Phys. 2013, 46 (15), 155101.

(5) Huang, W.; Khan, T.; Chow, T. P. J. Electron. Mater. 2006, 35 (4), 726-732.

(6) Wang, X.; Saadat, O. I.; Xi, B.; Lou, X.; Molnar, R. J.; Palacios, T.; Gordon, R. G.; Palacios, T.; Gordon, R. G. Appl. Phys. Lett. 2012, 101 (23), 232109.

(7) Wang, X.; Dong, L.; Zhang, J.; Liu, Y.; Ye, P. D.; Gordon, R. G. Nano Lett. 2013, 13 (111), 594-599.

(8) Hellman, E. S.; Hartford, E. H. Appl. Phys. Lett. 1994, 64 (11), 1341-1343.

(9) Paisley, E. A.; Gaddy, B. E.; Lebeau, J. M.; Shelton, C. T.; Biegalski, M. D.; Christen, H. M.; Losego, M. D.; Mita, S.; Collazo, R.; Sitar, Z.; Irving, D. L.; Maria, J.-P. P. J. Appl. Phys. 2014, 115 (6), 64101.

(10) Chen, J.-J.; Hlad, M.; Gerger, A. P.; Gila, B. P.; Ren, F.; Abernathy, C. R.; Pearton, S. J. J. Electron. Mater. 2007, 36 (4), 368-372.

(11) Gila, B. P.; Hlad, M.; Onstine, A. H.; Frazier, R.; Thaler, G. T.; Herrero, A.; Lambers, E.; Abernathy, C. R.; Pearton, S. J.; Anderson, T.; Jang, S.; Ren, F.; Moser, N.; Fitch, R. C.; Freund, M. Appl. Phys. Lett. 2005, 87 (16), 163503.

(12) Wang, X. Applications of Vapor Deposition in Microelectronics and Dye-Sensitized Solar Cells, Harvard University, 2013.

(13) Kim, S. B.; Yang, C.; Powers, T.; Davis, L. M.; Lou, X.; Gordon, R. G. Angew. Chem. Int. Ed. 2016, 55, 10228-10233.

(14) de Rouffignac, P.; Sullivan, N.; Beaulieu, D.; Park, J.-S.; Hock, A.; Gordon, R. G. In Proceedings of the AVS Atomic Layer Deposition Conference; 2009.

(15) Doman, R. C.; Barr, J. B.; Mcnally, R. N.; Alper, A. M. J. Am. Ceram. Soc. 1963, 46, 313-316.

(16) Li, H. D.; Zhang, X. N.; Zhang, Z.; Mei, Z. X.; Du, X. L.; Xue, Q. K. J. Appl. Phys. 2007, 101 (10), 2005-2008.

(17) Gila, B. P.; Thaler, G. T.; Onstine, A. H.; Hlad, M.; Gerger, A.; Herrero, A.; Allums, K. K.; 
Stodilka, D.; Jang, S.; Kang, B.; Anderson, T.; Abernathy, C. R.; Ren, F.; Pearton, S. J. Solid. State. Electron. 2006, 50 (6), 1016-1023.

(18) Matocha, K.; Gutmann, R. J.; Chow, T. P. IEEE Trans. Electron Devices 2003, 50 (5), 1200-1204.

(19) E. H. Nicollian andA. Goetzberger. Bell Syst. Tech. J. 1967, 46 (6), 1055-1033.

(20) Brown, D. M.; Gray, P. V. J. Electrochem. Soc. 1966, 155 (7), 760-766.

(21) Yang, S.; Tang, Z.; Wong, K. Y.; Lin, Y. S.; Liu, C.; Lu, Y.; Huang, S.; Chen, K. J. IEEE Electron Device Lett. 2013, 34 (12), 1497-1499.

(22) Bin Lu, B.; Min Sun, M.; Palacios, T. IEEE Electron Device Lett. 2013, 34 (3), 369-371.

Table of Content Figure
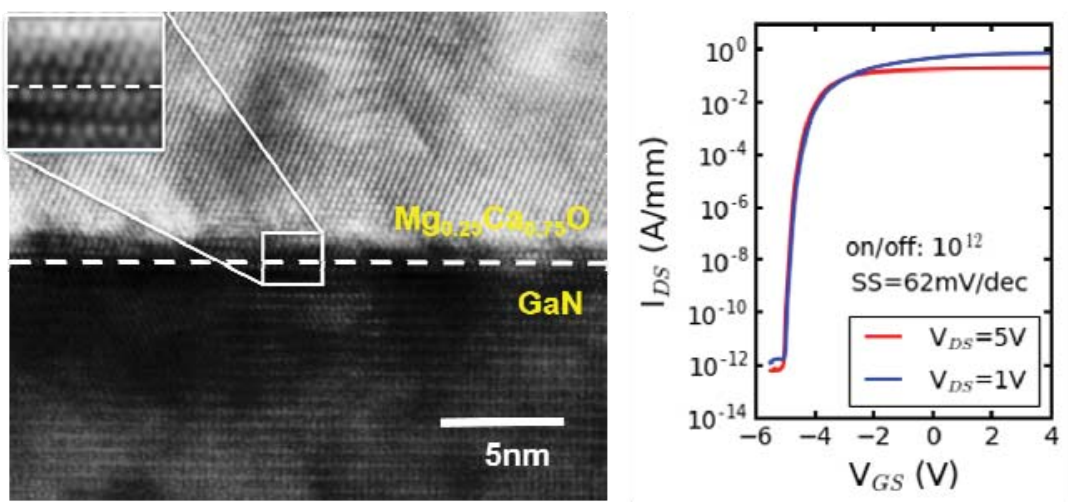


\section{Epitaxial Growth of $\mathrm{Mg}_{\mathrm{x}} \mathrm{Ca}_{1-\mathrm{x}} \mathrm{O}$ on $\mathrm{GaN}$ by Atomic Layer Deposition}

Xiabing Lou ${ }^{\dagger}$, Hong Zhou ${ }^{\ddagger}$, Sang Bok Kim ${ }^{\dagger}$, Sami Alghamdi ${ }^{\ddagger}$, Xian Gong ${ }^{\dagger}$, Jun Feng ${ }^{\dagger}$, Xinwei Wang ${ }^{\dagger}$, Peide D. Ye ${ }^{\ddagger}$, Roy G. Gordon ${ }^{\dagger}$

${ }^{\dagger}$ Department of Chemistry and Chemical Biology, Harvard University, Cambridge, Massachusetts

02138, United States

$¥$ School of Electrical and Computer Engineering and Birck Nanotechnology Center, Purdue

University, West Lafayette, Indiana 47906, United States

Correspondence to: gordon@chemistry.harvard.edu

Present Address:

\# School of Advanced Materials, Shenzhen Graduate School, Peking University, Shenzhen 518055, China

\section{XRR/XRD}

$\mathrm{Mg}_{\mathrm{x}} \mathrm{Ca}_{1-\mathrm{x}} \mathrm{O}$ grown on thermal oxide $(300 \mathrm{~nm} \mathrm{SiO} / \mathrm{Si}$ ) wafers was characterized by XRD and XRR for lattice spacing and thickness respectively. Each thermal oxide wafer was cleaned of organic contamination by exposure to UV light in air (UV-ozone treatment) for $5 \mathrm{~min}$ before being loaded into the deposition chamber. Both XRR and XRD characterization was performed with a Bruker D8 Discover system. 


\section{Deposition conditions for ALD}

The magnesium and calcium precursors were kept in sealed bubblers at $110{ }^{\circ} \mathrm{C}$ and $140{ }^{\circ} \mathrm{C}$ respectively in two separate ovens, and were delivered into the reaction chamber with controlled volumes of $\mathrm{N}_{2}$ carrier gas. The deposition was performed at a substrate temperature of $310^{\circ} \mathrm{C}$. The dosing sequence was $\left[\left(\mathrm{Ca}-\mathrm{H}_{2} \mathrm{O}\right)_{\mathrm{y}}-\left(\mathrm{Mg}-\mathrm{H}_{2} \mathrm{O}\right)_{\mathrm{x}}\right]_{\mathrm{n}}$. Each metal precursor dose was followed by a water dose. The composition was adjusted by varying the dosing ratio between the $\mathrm{Mg}$ and $\mathrm{Ca}$ cycles. The GaN substrates were treated with UV-Ozone for $5 \mathrm{~min}$ then followed with $20 \%$ ammonium hydroxide soaking for $20 \mathrm{~min}$ prior to ALD deposition. The water contact angle on newly received $\mathrm{GaN}$ substrate was $70^{\circ}$. This hydrophobic surface was due to the adsorbed organic compounds. After removal of organic contamination by UV-Ozone treatment, the contact angle decreased down to $18^{\circ}$ since the surface was turned into $\mathrm{Ga}_{2} \mathrm{O}_{3}$. The contact angle of $\mathrm{GaN}$ surface further decreased to $9^{\circ}$ after ammonium hydroxide treatment. This was because the ammonium hydroxide could effectively remove the $\mathrm{Ga}_{2} \mathrm{O}_{3}$ and expose the clean and highly hydrophilic GaN surface for deposition. ${ }^{1}$ Such surface is highly favorable for a Frank-van der Merwe (layer-by-layer) growth in ALD.

\section{FIB/TEM}

Transmission electron microscopy (TEM) images were taken with a JEOL-2100 TEM at the Harvard Center for Nanoscale Systems (CNS). The TEM cross-section sample preparation was done with a FEI Helios 660 focused ion beam (FIB) system.

Top view TEM of $\mathrm{Mg}_{0.25} \mathrm{Ca}_{0.75} \mathrm{O} / \mathrm{Si}_{3} \mathrm{~N}_{4}$ membrane and its diffraction pattern in Fig. S1 confirmed that no phase separation into $\mathrm{MgO}$ and $\mathrm{CaO}$ occurred. 

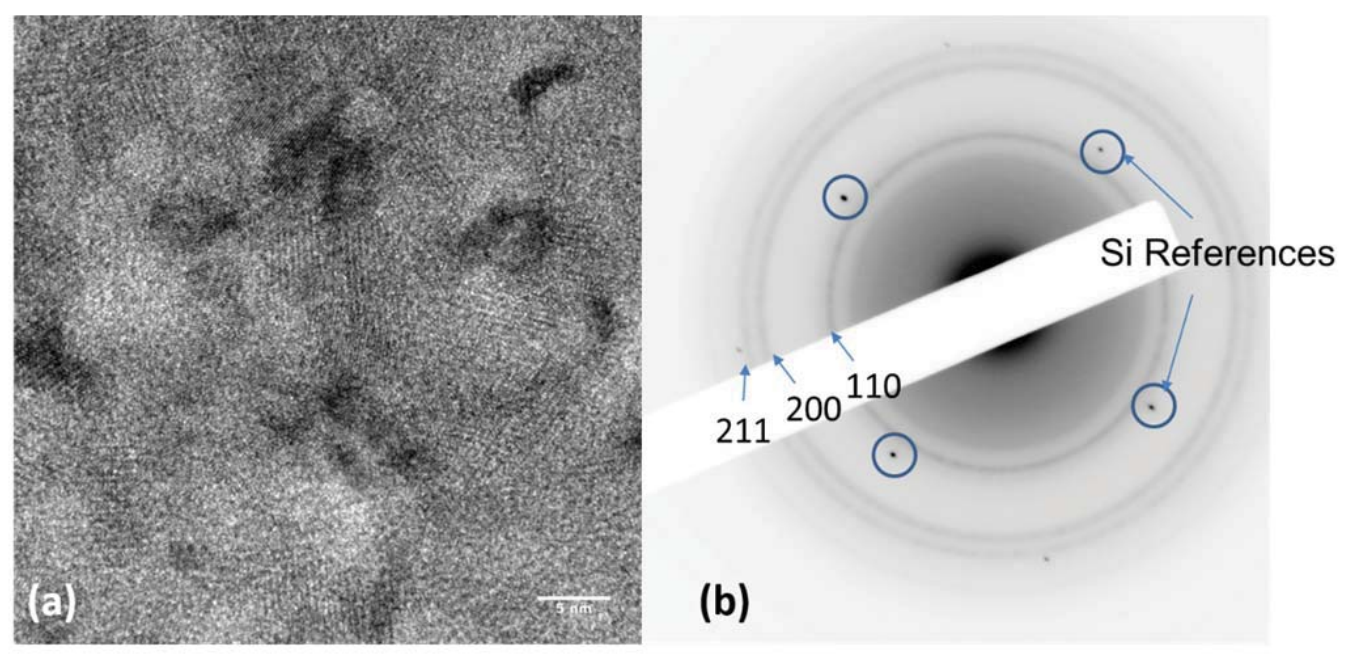

Figure S1. (a) Top view of $\mathrm{Mg}_{0.25} \mathrm{Ca}_{0.75} \mathrm{O} / \mathrm{Si}_{3} \mathrm{~N}_{4}$ membrane. (b) TEM diffraction pattern of the area in (a).

In the cross section TEM diffraction patterns (Fig. S2), as Mg content increases, the $\mathrm{MgCaO}(-200)$ and (-111) diffraction spots shift farther from the center of the pattern. This trend is accord with the HRXRD results shown in Fig 2. The $\mathrm{MgCaO}$ (111) diffraction spots are overlapped with the $\mathrm{GaN}$ (0002) spot.
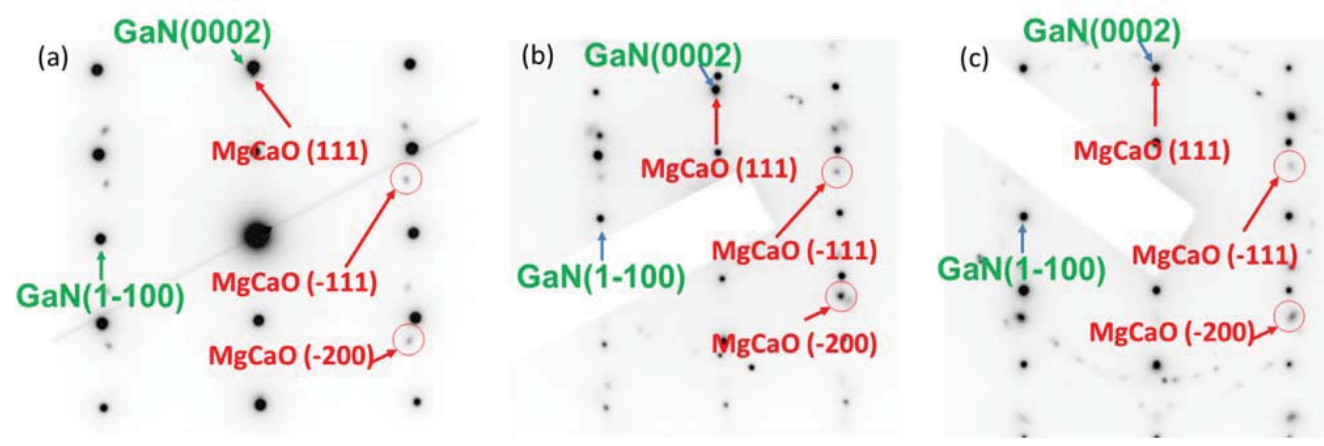

Figure S2. TEM diffraction pattern of cross sectional $\mathrm{Mg}_{\mathrm{x}} \mathrm{Ca}_{1-\mathrm{x}} \mathrm{O} / \mathrm{GaN}$ interface sample. The zone axis is $\mathrm{GaN}$ [-1 -1 2 0]. (a) $\mathrm{Mg}_{0.25} \mathrm{Ca}_{0.72} \mathrm{O} / \mathrm{GaN}$; (b) $\mathrm{Mg}_{0.51} \mathrm{Ca}_{0.49} \mathrm{O} / \mathrm{GaN}$; (c) $\mathrm{Mg}_{0.72} \mathrm{Ca}_{0.28} \mathrm{O} / \mathrm{GaN}$.

\section{RBS}

Rutherford Backscattering Spectroscopy (RBS) was done at the Department of Physics and Astronomy, Rutgers University. 


\section{MOS-capacitor}

Epi-layers GaN (5 $5 \mathrm{~m}$ thick) grown on sapphire substrates were purchased from MTI with resistivity of $0.02 \Omega \cdot \mathrm{cm}$. The GaN wafers were treated with UV-ozone for organic removal and then soaked for $20 \mathrm{~min}$ in $20 \%$ aqueous ammonium hydroxide to remove native oxides. After pretreatment the samples were patterned into circular capacitors by photo lithography. $300 \mathrm{~nm} \mathrm{Al}$ metal was then deposited onto the dielectric and the remaining photoresist with thermal evaporation. After lift-off overnight, the "top-to-top" capacitor structure was formed as shown in

\section{Fig. S3}

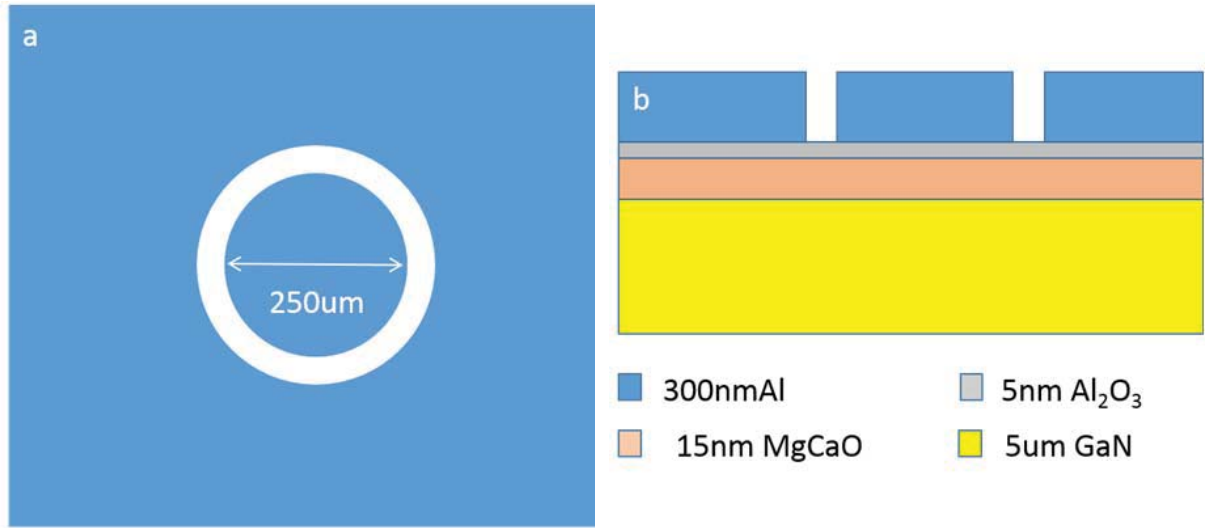

Figure S3. MOS-capacitor for CV measurement. (a) Top view of the MOS-capacitor. (b) Side view of the MOS-capacitor.

\section{MOS-HEMT}

The AlGaN/GaN MOS-HEMT structure was grown on a $\mathrm{Si}$ (111) substrate, consisting of, a 5-nm $\mathrm{Al}_{2} \mathrm{O}_{3}$ capping layer, a 10-nm $\mathrm{Mg}_{0.25} \mathrm{Ca}_{0.75} \mathrm{O}$ epitaxial oxide, a 2-nm $\mathrm{GaN}$ capping layer, a 17-nm $\mathrm{Al}_{0.26} \mathrm{Ga}_{0.74} \mathrm{~N}$ barrier, a 1-nm AlN spacer, a GaN channel, and a $800 \mathrm{~nm}$ GaN buffer. Device fabrication started with mesa isolation by $\mathrm{Cl}_{2} / \mathrm{BCl}_{3}$ etching to a depth of $80 \mathrm{~nm}$. Then, Ohmic contacts were formed by depositing Ti/Al/Ni/Au $(20 / 100 / 40 / 50 \mathrm{~nm})$ followed by $775{ }^{\circ} \mathrm{C}$ rapid thermal anneal in $\mathrm{N}_{2}$ atmosphere. The sheet resistance $\left(\mathrm{R}_{\mathrm{SH}}\right)$ and contact resistance $\left(\mathrm{R}_{\mathrm{C}}\right)$ were determined to be $480 \Omega / \square$ and $0.3 \Omega \cdot \mathrm{mm}$ through transfer length method (TLM). Then gate oxides were deposited by ALD. The gate metal is formed by deposition of Ni/Au (30/50 nm) with lift-off process. Electrical measurements were performed with a Keysight E4980A LCR meter. 


\section{MOS-HEMT measurement conditions}

$\mathrm{I}_{\mathrm{D}}-\mathrm{V}_{\mathrm{DS}}$ : The $\mathrm{V}_{\mathrm{DS}}$ is swept from 0 to $10 \mathrm{~V}$ and the $\mathrm{V}_{\mathrm{GS}}$ is stepped from $5 \mathrm{~V}$ to $-5 \mathrm{~V}$ with $-0.5 \mathrm{~V}$ as the step.

$\mathrm{I}_{\mathrm{D}}-\mathrm{V}_{\mathrm{GS}}$ : The $\mathrm{V}_{\mathrm{GS}}$ is swept from $4 \mathrm{~V}$ to $-5.5 \mathrm{~V}$ with $-0.05 \mathrm{~V}$ as a step at $\mathrm{V}_{\mathrm{DS}}=1 \mathrm{~V}$ and $5 \mathrm{~V}$.

\section{AC conductance method to extract $D_{\text {it }}$}

The AC conductance method is one of the most sensitive methods to determine $\mathrm{D}_{\mathrm{it}}$. The equivalent circuits of the MOS capacitor are as following in Fig S4:

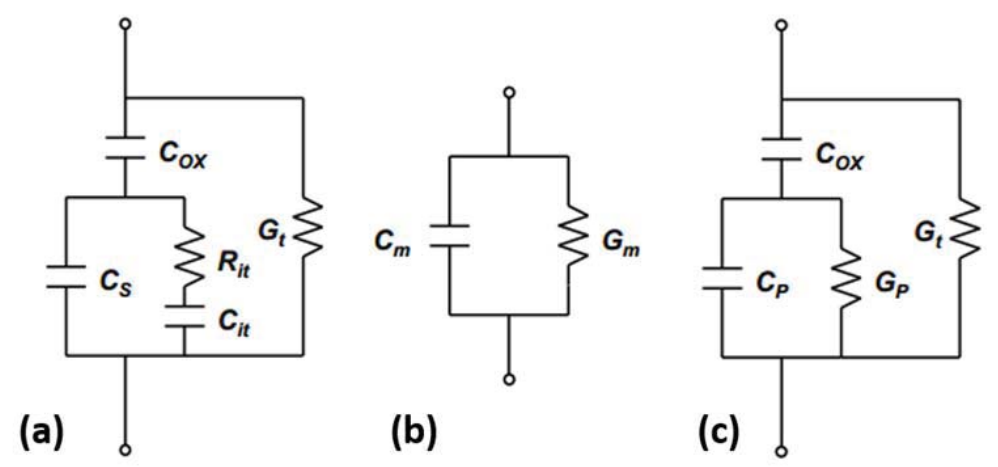

Figure S4. Equivalent circuits of MOS capacitor; (a) an equivalent circuit model of the

MOS capacitor, (b) the measured circuit, (c) the simplified circuit of (a).

The extracted $\mathrm{D}_{\mathrm{it}}$ can be expressed by the following equation:

$$
D_{i t}=\frac{2.5}{q}\left(\frac{G_{p}}{\omega}\right)_{\max }
$$

where $\mathrm{G}_{\mathrm{p}} / \omega$ is

$$
\frac{G_{p}}{\omega}=\frac{\omega\left(G_{m}-G_{t}\right) C_{o x}^{2}}{G_{m}^{2}+\omega^{2}\left(C_{o x}-C_{m}\right)^{2}}
$$

$\mathrm{C}_{\mathrm{ox}}, \mathrm{C}_{\mathrm{m}}, \mathrm{G}_{\mathrm{m}}$ and $\mathrm{G}_{\mathrm{t}}$ are oxide capacitance, measured capacitance, measured conductance, and measured oxide tunnel conductance, respectively. 

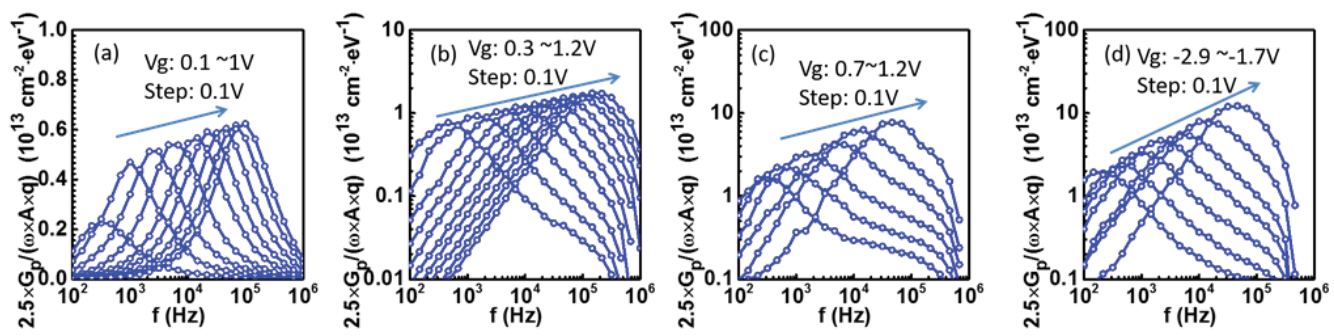

Figure S5. $\mathrm{G}_{\mathrm{p}} / \omega$ vs. frequency at $150{ }^{\circ} \mathrm{C}$. (a) $\mathrm{Al}_{2} \mathrm{O}_{3}(5 \mathrm{~nm}) / \mathrm{Mg}_{0.25} \mathrm{Ca}_{0.75} \mathrm{O}(15 \mathrm{~nm}) / \mathrm{GaN}$. (b) $\mathrm{Al}_{2} \mathrm{O}_{3}(5 \mathrm{~nm}) / \mathrm{Mg}_{0.51} \mathrm{Ca}_{0.49} \mathrm{O}(15 \mathrm{~nm}) / \mathrm{GaN}$.

(c) $\quad \mathrm{Al}_{2} \mathrm{O}_{3}(5 \mathrm{~nm}) / \mathrm{Mg}_{0.72} \mathrm{Ca}_{0.28} \mathrm{O}(15 \mathrm{~nm}) / \mathrm{GaN}$.

$\mathrm{Al}_{2} \mathrm{O}_{3}(20 \mathrm{~nm}) / \mathrm{GaN}$;

The trap energy level within the bandgap can be expressed as:

$$
\Delta E=\mathrm{kT} \times \ln \left(\frac{\sigma V_{T} N}{2 \pi \mathrm{f}}\right)
$$

where $\mathrm{k}, \mathrm{T}, \sigma, \mathrm{V}_{\mathrm{T}}, \mathrm{N}$, and $\mathrm{f}$ are Boltzmann constant, temperature, trap capture cross section, thermal velocity, conduction band density, and conductance peak corresponding frequency, respectively.

XPS

X-ray photoelectron spectroscopy (XPS) was taken by a Thermo Scientific K-alpha system. In Fig S6, the absence of $\mathrm{Ga}$ and $\mathrm{N}$ signals from substrate in $\mathrm{Mg}_{0.25} \mathrm{Ca}_{0.75} \mathrm{O} / \mathrm{GaN}$ indicates that the surface of GaN is fully covered by $\mathrm{MgCaO}$ film. Since the penetration depth of XPS and the film thickness in this case were both about $10 \mathrm{~nm}$, any missing areas of the film would result in detectable substrate signals. Therefore, the absence of substrate signal indicates that the film is uniformly covering the GaN surface.

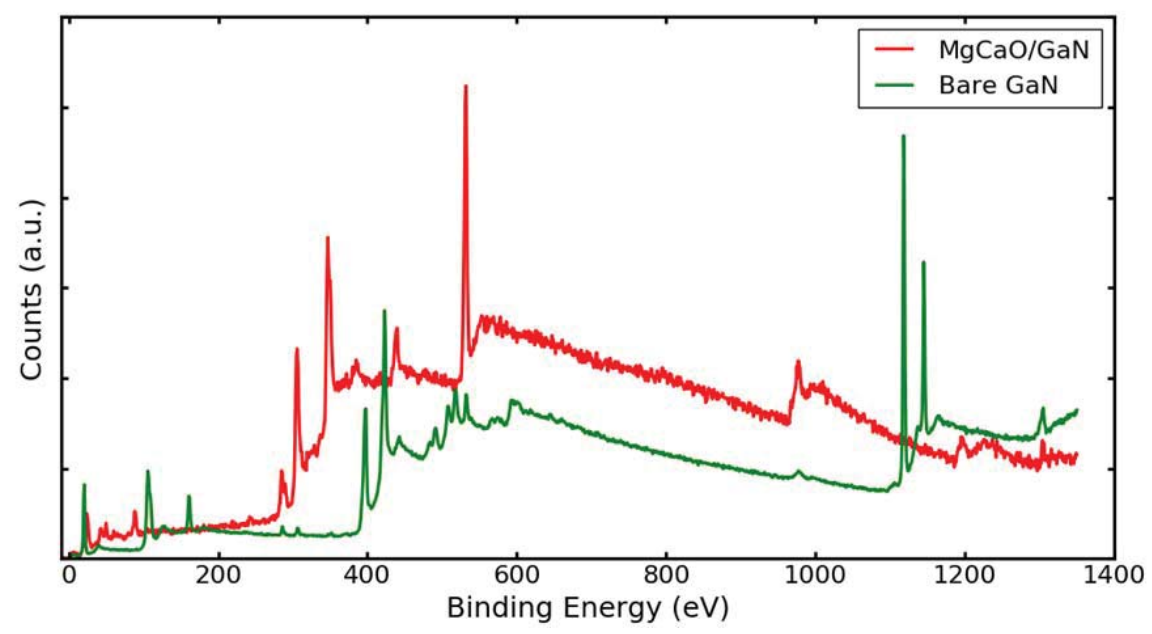

Figure S6. XPS spectrum of bare $\mathrm{GaN}$ (green) and $\mathrm{Mg}_{0.25} \mathrm{Ca}_{0.75} \mathrm{O}(10 \mathrm{~nm}) / \mathrm{GaN}$ (red). 
AFM

The AFM study is done with an Asylum MFP-3D AFM System. The similar RMS values obtained from before and after the deposition indicate that the film has uniform thickness.

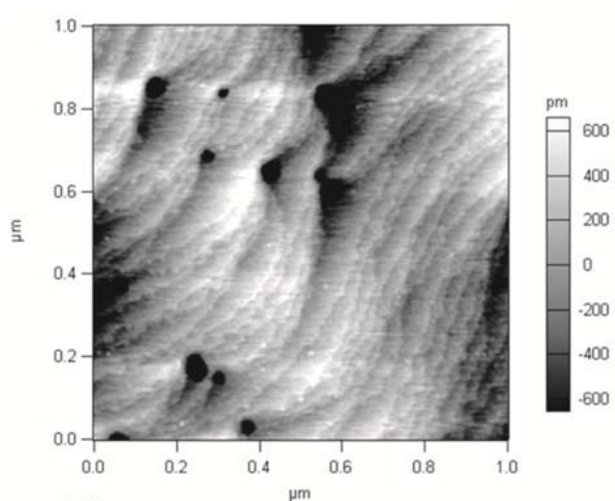

(a)

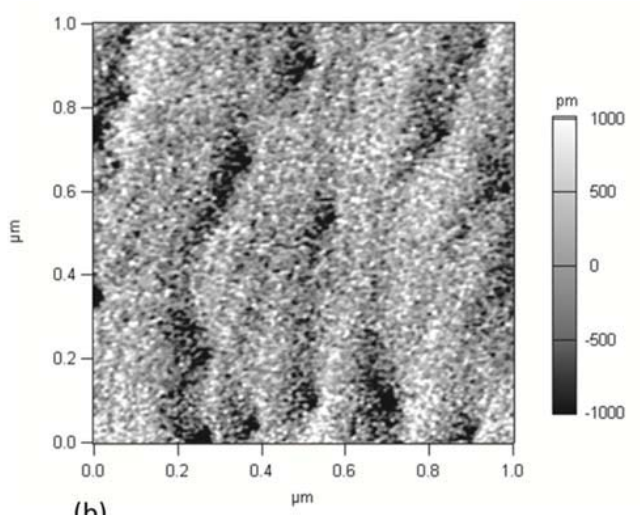

(b)

Figure S7. (a) $\mathrm{GaN}$ surface, $\mathrm{RMS}=0.37 \mathrm{~nm}$; (b) $\mathrm{Mg}_{0.25} \mathrm{Ca}_{0.75} \mathrm{O}(10 \mathrm{~nm}) / \mathrm{GaN}$ surface, $\mathrm{RMS}=0.47$ $\mathrm{nm}$

\section{FFT analysis of crosssectional TEM images.}

Fast Fourier Transform (FFT) analysis is employed to study the in-plane lattice mismatch. By measuring the lateral distance of corresponding spots in the FFT images with pixel as unit, the in-plane lattice mismatch can be calculated with $\left(\mathrm{L}_{\mathrm{sub}}-\mathrm{L}_{\text {film }}\right) / \mathrm{L}_{\text {film. }}$. The error range of in-plane mismatch from FFT is about $\pm 1 \%$ due to the limited image resolution. The results show that the in-plane mismatch is in good agreement with the out-of-plane mismatch.

\begin{tabular}{|c|c|c|c|}
\hline Film composition & $\mathrm{Mg}_{0.25} \mathrm{Ca}_{0.75} \mathrm{O}$ & $\mathrm{Mg}_{0.49} \mathrm{Ca}_{0.51} \mathrm{O}$ & $\mathrm{Mg}_{0.72} \mathrm{Ca}_{0.28} \mathrm{O}$ \\
\hline \multicolumn{4}{|l|}{ FFT of $\mathrm{MgCaO}$ film } \\
\hline \multicolumn{4}{|l|}{ FFT of GaN substrate } \\
\hline Lateral distance of film & $104 p^{*}$ & $107 p$ & $64 p$ \\
\hline Lateral distance of Sub & $108 p$ & $110 p$ & $63 p$ \\
\hline FFT lattice mismatch & $+3.8 \%$ & $+2.8 \%$ & $-1.5 \%$ \\
\hline XRD lattice mismatch & $+3.1 \%$ & $+2.4 \%$ & $-1.2 \%$ \\
\hline
\end{tabular}

Figure S8. Fast Fourier Transform analysis of $\mathrm{MgCaO} / \mathrm{GaN}$ crosssection TEM images. The original images are from Fig 2. * "p" stands for pixels in the image. 


\section{Reference}

(1) King, S. W.; Barnak, J. P.; Bremser, M. D.; Tracy, K. M.; Ronning, C.; Davis, R. F.; Nemanich, R. J. J. Appl. Phys. 1998, 84 (9), 5248-5260. 